\title{
Physico-Mechanical Properties of Bricks Manufactured using Cement Kiln Dust
}

\author{
Bashar B. Tarazi, Abdel Moniem Y. Sanad, Mohamed M. El-Attar, Dina M. Sadek
}

\begin{abstract}
- the actual increase in global industrial production and manufacturing, produces a continuous increase in amount of industrial waste and continues to emit an all-time high amount of air pollutants and greenhouse gas emissions. To fight and mitigate these phenomena, proper Waste Management became the pillar of most environmental strategies worldwide. By reduction of consumption, re-use of goods and recycling of products, waste management aims to preserve the resources and to protect the environment. The Cement industry is one of the most important industrial sectors for society development; however it also has significant negative environmental impacts due to its emissions and production of waste. Cement kiln dust (CKD) is an industrial waste or by product which results from cement manufacturing. CKD is fine grained, solid, highly alkaline particulate material chiefly composed of oxidized, anhydrous, micron-sized particles collected from electrostatic precipitators during the production of cement clinker. This research examines the effects of using large amounts of CKD to replace the cement content in the fabrication of solid cement bricks. It is triggered by the quadruple objectives of reducing the amount of cement consumption, disposing efficiently of its industrial waste and producing economic bricks with safe strength. The purpose of this paper is to assess the properties of solid cement bricks containing different amounts of CKD. Cement bricks produced using different amounts of CKD were tested to find their properties and final comparison has been made to identify the effect of using different CKD/Cement ratio on the performance of bricks compared to the reference specimen produced using cement only with no CKD. For the brick mixes, Ordinary Portland cement (OPC), with two cement content of $200 \mathrm{~kg} / \mathrm{m}^{3}$ and $250 \mathrm{~kg} / \mathrm{m}^{3}$ were used throughout this investigation. The physical properties; unit weight, water absorption and mechanical properties; compressive strength, flexural strength, of the produced bricks were determined. Results showed that partial replacement of OPC with CKD reduces the brick compressive strength by $18 \%$ to $23 \%$ for CKD/OPC ratio of $30 \%$ and by $36 \%$ for CKD/OPC ratio of $50 \%$ and in all cases the strength remains largely higher than the standard limit for load bearing bricks.
\end{abstract}

Index Terms: Cement Kiln Dust (CKD), Portland cement, Bricks physical and mechanical properties.

\section{INTRODUCTION}

Globalneed for cement-based materialshas increased drastically for construction industry worldwide.

Revised Manuscript Received on February 15, 2020.

* Correspondence Author

Bashar B. Tarazi, Construction and Building Engineering, Arab Academy for Science, Technology and Maritime Transport/ Cairo, Egypt.

Abdel MoniemY. Sanad, Professor, Construction and Building Engineering, Arab Academy for Science, Technology and Maritime Transport.

Mohamed M. El-Attar, Professor, Department of Structure Engineering, Faculty of Engineering, Cairo University, Egypt.

Dina M. Sadek, Building Materials Research and Quality Control Institute, Housing and Building National Research Center, Cairo, Egypt

(C) The Authors. Published by Blue Eyes Intelligence Engineering and Sciences Publication (BEIESP). This is an open access article under the CC BY-NC-ND license (http://creativecommons.org/licenses/by-nc-nd/4.0/)
The manufacturing process of Cement is well known to produce large quantities of industrial solid waste and emits larges amount of Carbon Dioxide $\left(\mathrm{CO}_{2}\right)$ that traps solar radiations in the atmosphere andresults inincrease of global temperature. The concentration of $\mathrm{CO}_{2}$ hasincreased tremendously since the pre-industrialera[1] with the Cement industry being one of the major contributors. The production ofPortland cement is believed tocontribute by $5-7 \%$ to the global $\mathrm{CO}_{2}$ emissions and is urgently needed to be reduced. Looking at the amount of waste and $\mathrm{CO}_{2}$ produced by the concreteindustry and their corresponding damaging effects, the environmental protectionregulations in most countriesimposed strict limits for emissions which restricted the cement production process and made itmore expensive.Therefore, supplementary cementing materials (SCM)have been widely encourage to be used as partial replacement to Portland cement(OPC)including industrial by-products like cement kiln dust(CKD), and natural pozzolanicmaterials like burnt clay (BC). Thesesiliceous or aluminousmaterials, which are similar to raw materialsused inmanufacturing PC, exhibit cementitious and/or pozzolanicproperties due to the physical and chemical properties[2,3].

CKD is a finepowdery material generated as by-product ofcement manufacturingprocess and is similar in appearance to Portland cement. It is composedofmicron-sized particles collected from electrostaticprecipitators during the production of cement clinker and classified into four categories, depending upon the kiln process used and thedegreeof separation in the dust collection system[4]. The CKD contains several beneficial elements as; silica, sulfates, chlorides, alkalis and free lime. Recycling CKD represents great financial benefit in addition to the positive impact on the environment andhuman health and deserved intensive efforts to be exerted worldwideto promote its applications. Actually, there is several techniqueand beneficial application of cement kiln dust reuse [5]:

- Agriculture: potash/lime source and animal feed.

- Civil engineering: fill, soil stabilization, fly ash stabilization,and blacktop filler.

- Building materials: lightweight aggregates, blocks, low strength concrete, and masonrycement.

- $\quad$ Sewage and water treatment: coagulation aid and sludge stabilization.

- Pollution control: Sulphur absorbent, waste treatment, and solidification

Thegoal ofthe current work is to share the research efforts directed toavail of CKD through utilization of such industrial by-product in manufacturing environment friendly constructionmaterials, Bricks that have vastapplications in the construction industry and could use large amount of such waste in a beneficial and safe manner. 
Previous research on the reuse of CKD as replacement of OPC has been carried out for Concrete or Mortar mixes. In 2002, Udoeyo and Hyeestudied the compressive strength of concrete when OPC isreplaced by CKD (20\%, 40\%, 60\%, $80 \%$, and $100 \%$ ) at water/cement ratio of 0.65 .

The compression tests wereconducted at $1,3,7$, and 28 days. The results reportedthat the compressive strengthdecreased slightly with CKD content up to $40 \%$, then it decreases sharply above this percentage [6]. In 2014, Najim et al. studied the effect of replacing $10 \%, 20 \%$, and $30 \%$ of cement with CKDon the compressive strength of Mortar. Standard mineral sand was used and the w/c ratio was 0.40 for the OPC mortar, and the mix proportion was 1:3 (cement: sand). It was reported that there is a progressive reduction in compressive strength with increasing CKD percentage replacement at all tested ages. The present work use CKD to replaceOPC for manufactory solid cement bricks [7]. To achieve this goal, several bricks specimens were made using different ratio of CKD/OPC. All specimens where tested and their physical and mechanical properties defined. A final comparison of the effect of CKD/OPC ratio is presented to show the reduction in strength and the performance of using different amount of CKD in Bricks manufacturing.

\section{MATERIALS}

Ordinary Portland Cement (OPC) produced by Cemex Cement Company and CKD generation from Helwan Cement Companywere used in this work, where OPCconforms to the European Standard [8] and chemical composition shown in Table 1. For bricks production, crushed stone with nominal maximum size $14 \mathrm{~mm}$, and standard mineralsand was used with amount of water, whereas the mix proportionwas 1:1.5 (sand: coarse). Sieve analysis test was conducted and the grading curve for the used coarse and sand is shown in Fig. 1.

TABLE 1

Chemical composition of OPC and CKD

\begin{tabular}{|c|c|c|}
\hline Materials & OPC & CKD \\
\hline $\mathrm{SiO}_{2}$ & 21.25 & 9.70 \\
\hline $\mathrm{Al}_{2} \mathrm{O}_{3}$ & 4.74 & 2.71 \\
\hline $\mathrm{Fe}_{2} \mathrm{O}_{3}$ & 2.90 & 2.61 \\
\hline $\mathrm{CaO}$ & 63.49 & 58.30 \\
\hline $\mathrm{MgO}$ & 0.80 & 1.51 \\
\hline $\mathrm{SO}_{3}$ & 2.40 & 4.93 \\
\hline $\mathrm{Na}_{2} \mathrm{O}$ & 0.80 & 0.72 \\
\hline $\mathrm{K}_{2} \mathrm{O}$ & 0.40 & 2.42 \\
\hline $\mathrm{Cl}$ & 0.01 & 3.51 \\
\hline L.O.I & 1.30 & 13.00 \\
\hline
\end{tabular}

Solid cement bricks dimensions were $25 \times 12 \times 6 \mathrm{~cm}$ and the manufacturing process was the following:

1. Coarse aggregate are placed in the mixer, followed by fine aggregate, then content is dry-mixed for about two minutes.

2. Cement or Cement pre-mixed with CKD is added to the aggregates and dry-mixed for another two minutes.

3 . Water is added to the content and mixed for three minutes to get homogenous mixture (shown inFig.2).

4. Fresh mix is placed in the mechanical press, vibrated and compacted. Fig.3 shows the pressing process and the bricks justafter pressing.

5. After manufacturing, the bricks are left in open air for 24 hours, then are cured by sprinkling water twice a day for 28 days. 


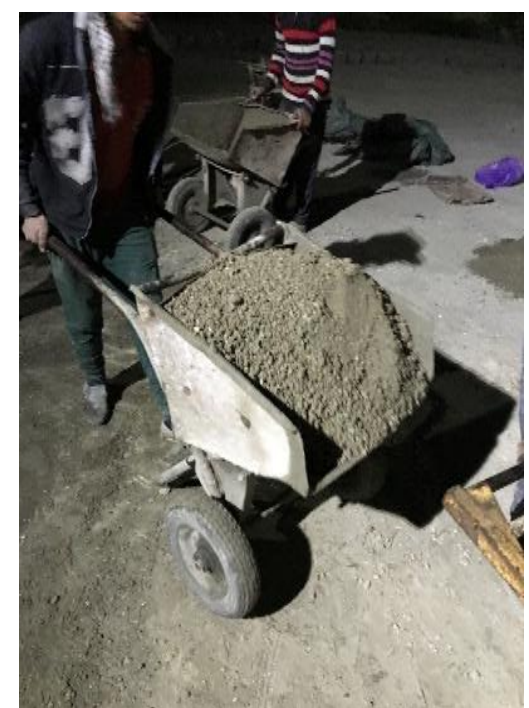

Fig. 2. Fresh mix.

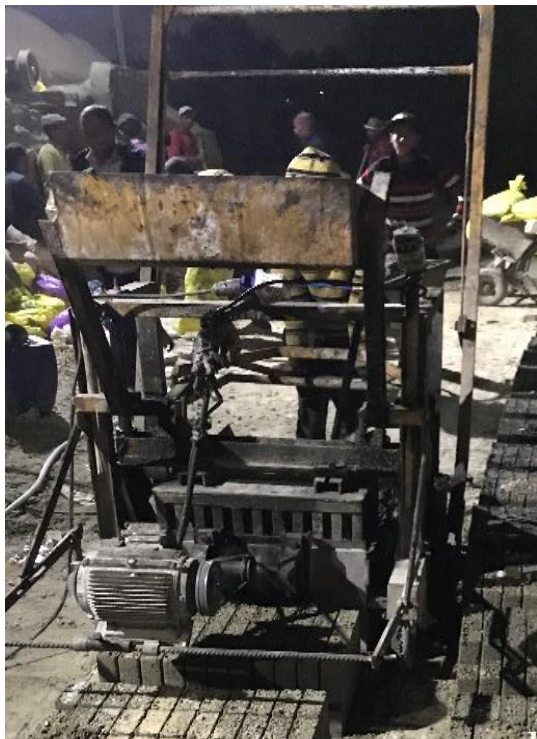

Fig. 3. Mechanical press.

\section{TEST PROCEDURES}

All tests were conducted according to ASTM C67-2018[9] to determine the physical properties (unit weight and water absorption) and mechanical properties (compressive strength, and flexure strength). Unit weighttests were conducted after 28 days from manufacturing, samples were placed in oven at a temperature of $100^{\circ} \mathrm{C}$ for 24 hours until the weight became constantas shown in Fig. 4. Samples were left to cool for one hour then weighted by using digital balance to get dry weight. The unit weight of the bricks was calculated by dividing the dry weight of each sample by its volume: Unitweight $(\gamma)=$ $\frac{\text { dry weight }}{\text { volume of the brick }}\left(\mathrm{kg} / \mathrm{m}^{3}\right)$.

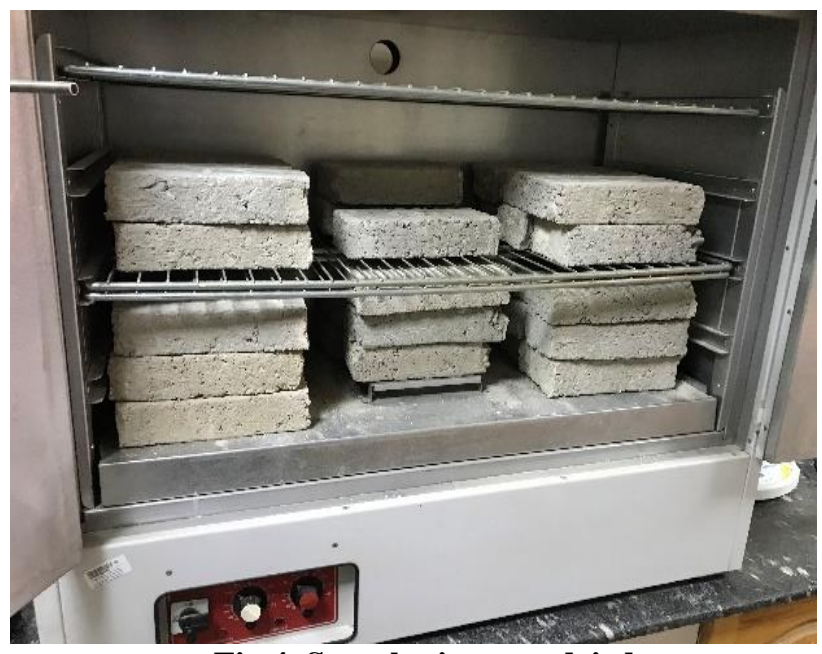

Fig.4. Samples in oven-dried.

Absorption tests were conducted by drying the specimens to a constant weight at $105^{\circ} \mathrm{C}$, weighing it, immersing it in water for 24 hours as shown in Fig.5, then and weighing it again. The increase in weight divided by the original weight indicates the absorption (in $\mathrm{Kg} / \mathrm{m}^{3}$ ). The average absorption of five samples is calculated at the age of 28 days.

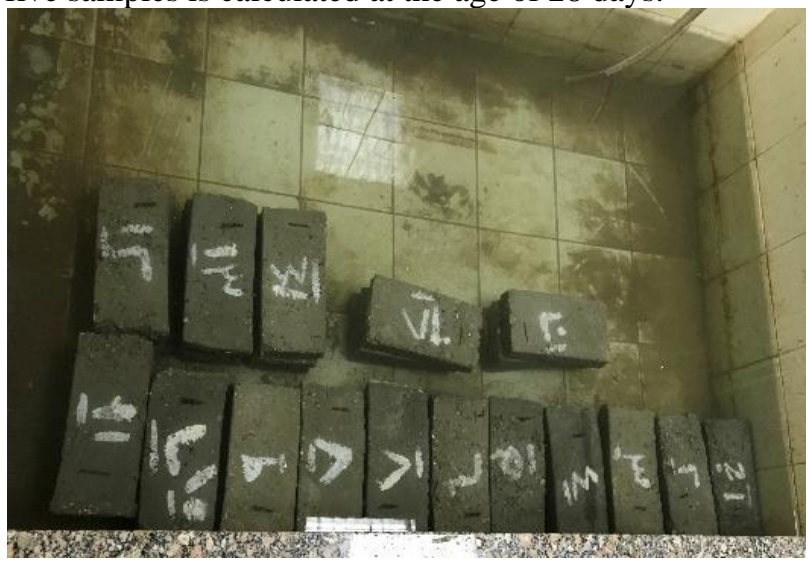

Fig. 5. Bricks immersed in water.

Compressive strength testwere conducted at the age of 28 days using the standard testing machine shown in Fig.6, with a maximum capacity of $2000 \mathrm{kN}$ and loading rate of $10 \mathrm{KN}$ per second. The average measurement of five samples was calculated for each category of brick with the compressive strength $\left(\mathrm{F}_{\mathrm{c}}\right)$ equals: $\mathrm{F}_{\mathrm{C}}=\frac{F}{A_{c}}\left(\mathrm{~kg} / \mathrm{cm}^{2}\right)$, with $\mathrm{F}$ being the maximum recorded load in $\mathrm{kg}$ and $\mathrm{A}_{\mathrm{c}}$ is the measured cross-sectional area of specimen in $\mathrm{cm}^{2}$.

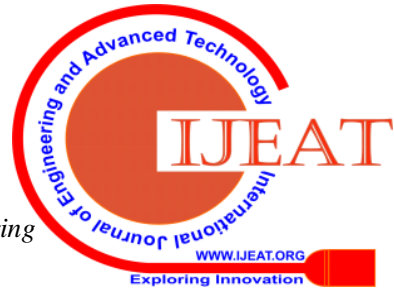




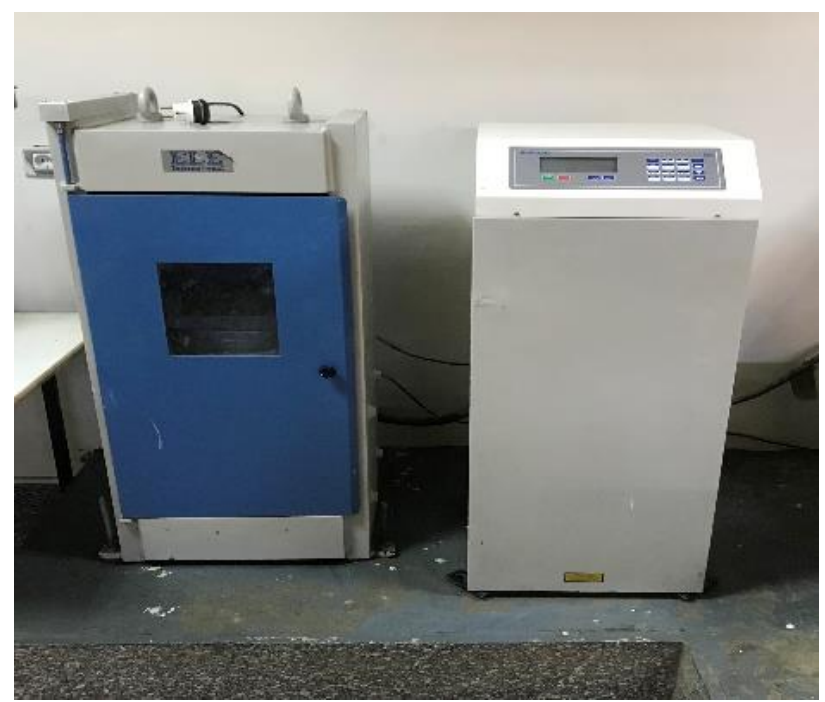

Fig. 6. Compression testing machine.

The Flexure strength tests were conducted after the same period of 28 days of manufacturing using the universal testing machine shown in Fig.7, with a maximum loading capacity of 60 tons. Each specimen was tested using three-point loading and flexure strength value for each category was based on the average of fivespecimen using the formula:

$\sigma=\frac{\mathrm{M}_{\max }}{\mathrm{I}} \mathrm{Y}\left(\mathrm{kg} / \mathrm{cm}^{2}\right)$

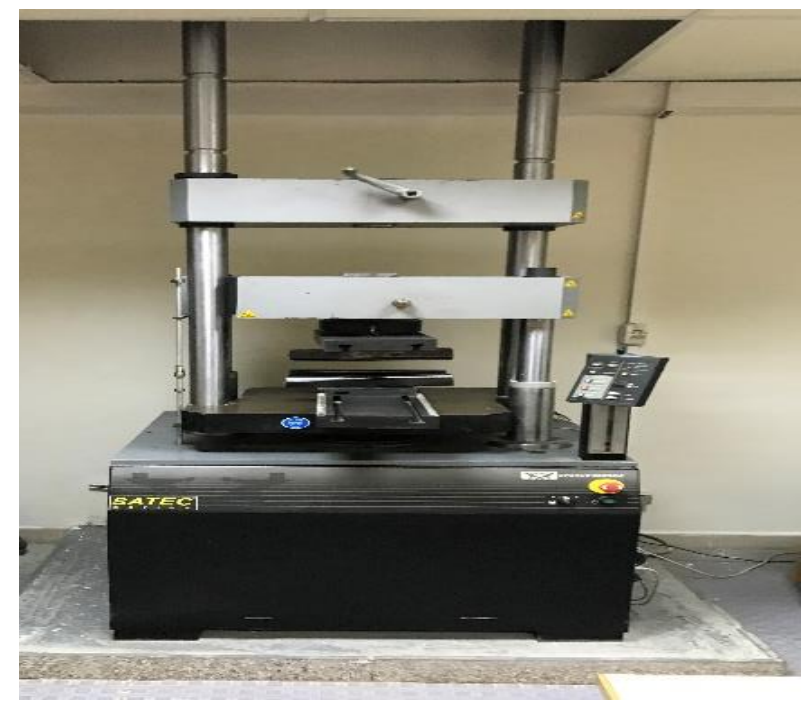

Fig.7. Universal testing machine.

\section{RESULTS AND DISCUSSIONS}

\section{Physical Characteristics}

\subsection{Unit weight}

Unit weight results are presented in Fig.8, for OPC solid cement bricks specimens prepared with and without CKD. For all brick mixtures, the unit weight decreases when amount of CKD increases. This decrease of unit weight is due to the lower density of CKD compared with OPC density and agrees with previous research [10]. The highest value of unit weight $\left(2214 \mathrm{~kg} / \mathrm{m}^{3}\right)$ was measured for brick mixture with cement content $250 \mathrm{~kg} / \mathrm{m}^{3}$ and $0 \%$ CKD (0\%CKD - 250OPC), while the lower value $\left(2055 \mathrm{~kg} / \mathrm{m}^{3}\right)$ was measured for mix with cement content $200 \mathrm{~kg} / \mathrm{m}^{3}$ and $50 \%$ CKD (50\%CKD -
200OPC). Using 30\% CKD, unit weight decreases by $1.4 \%$ and $2.8 \%$ for 250 and $200 \mathrm{~kg} / \mathrm{m}^{3}$ OPC content respectively. Using 50\% CKD, unit weight decreases by $5.3 \%$ for both OPC contents. All produced and tested bricks are classified as normal weight bricks according to ASTM C90 [11].

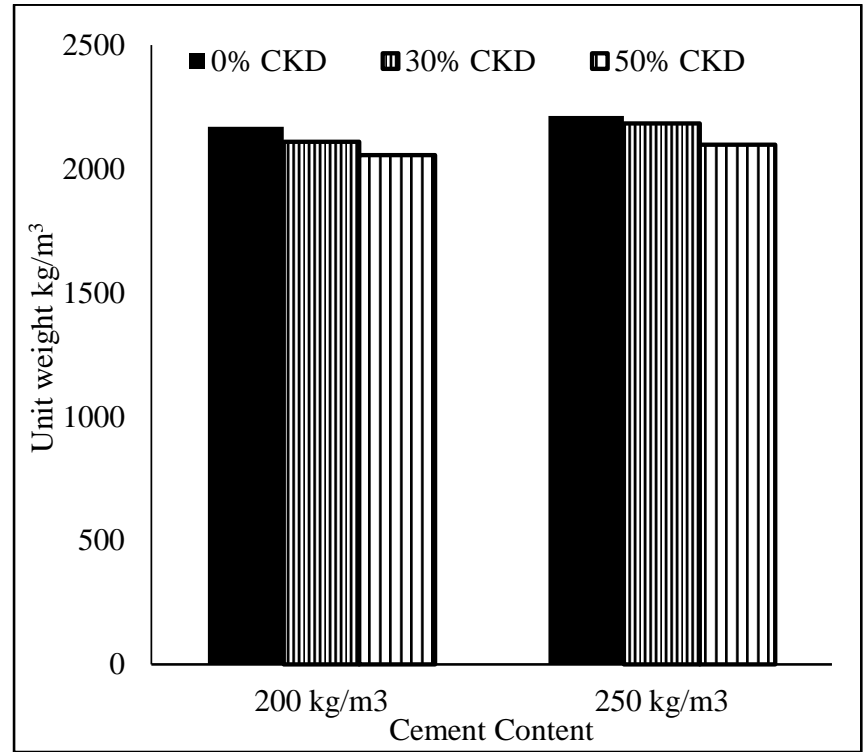

Fig.8. Unit weightof solid cement bricks at age 28 days.

\subsection{Water absorption}

Fig.9 shows that water absorption increases when percentage of CKD content increases and total water absorption is higher for $200 \mathrm{~kg} / \mathrm{m}^{3}$ mixes than for $250 \mathrm{~kg} / \mathrm{m}^{3}$ mixes. The highest value of water absorption $\left(137 \mathrm{~kg} / \mathrm{m}^{3}\right)$ was measured for mix code (50\%CKD-200OPC) while the lowestvalue $(111 \mathrm{~kg} / \mathrm{m} 3)$ was measured for mix code (0\%CKD- 250 OPC)using ordinary Portland cement with content $250 \mathrm{~kg} / \mathrm{m}^{3}$, and $0 \%$ $\mathrm{CKD}$ and all resultssatisfies the maximum limit for water absorption (i.e., $208 \mathrm{~kg} / \mathrm{m}^{3}$ ) according to ASTM C90 [11].

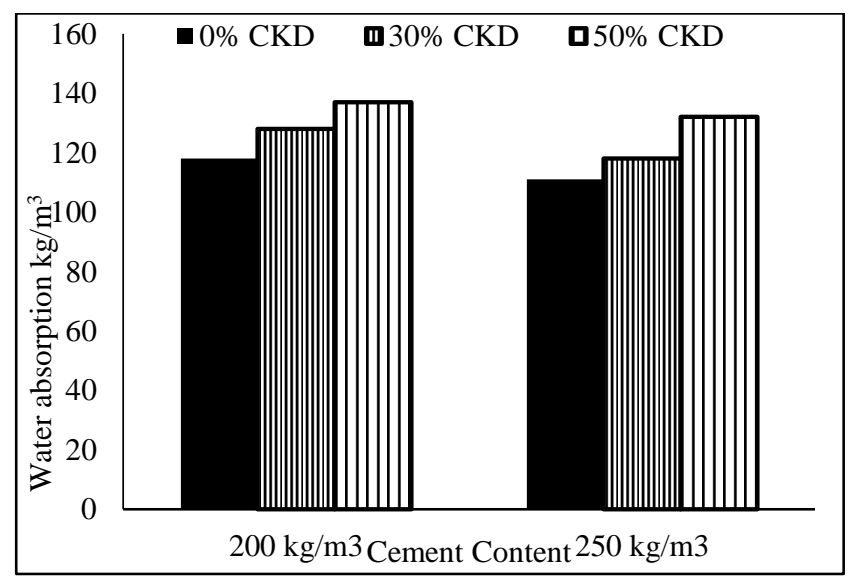

Fig. 9. Water absorption of solid cement bricks at age 28 days.

Published By: 


\section{Mechanical Characteristics}

\subsection{Compressive strength}

The compressive strength of the solid cement bricks containing OPC with different amounts of CKD isgraphically represented as a function of cement content in Fig. 10. As expected, thecompressive strength decreases with increasing content of CKD. However, the compressive strength loss is modest with regard to the amount of CKD used in the mix. Thus using 30\% CKD bricks resulted in reduction in compressive strength by $23 \%$ and $18 \%$ for 200 and 250 $\mathrm{kg} / \mathrm{m}^{3}$ respectively. While using $50 \%$ CKD decreased the compressive strength by only $36 \%$ for both OPC contents.

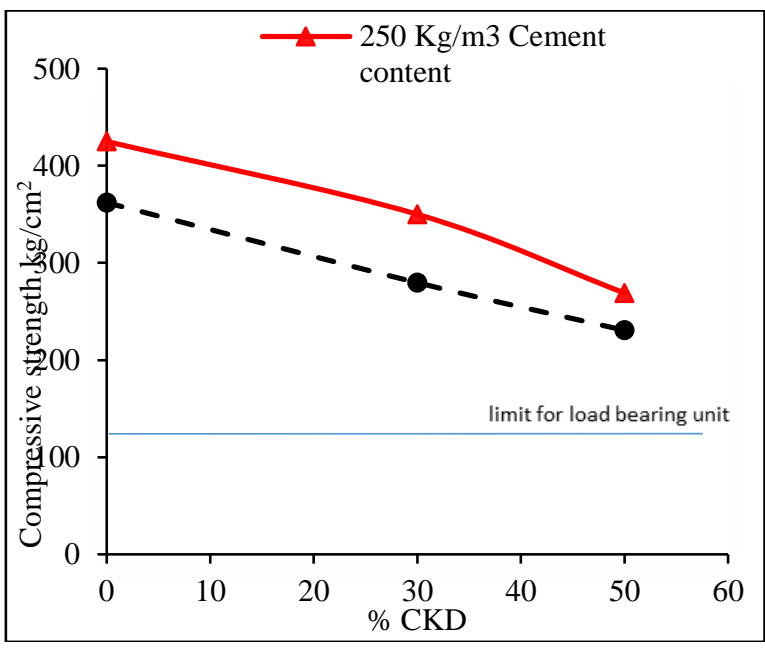

Fig. 10. Compressive strength of solid cement bricks at age 28 days.

The highest value of compressive strength $\left(425 \mathrm{~kg} / \mathrm{cm}^{2}\right)$ was achieved by the mix code (0\%CKD- 250OPC) forordinary Portland cementcontent of $250 \mathrm{~kg} / \mathrm{m}^{3}$, and no CKD while the lower value $\left(231 \mathrm{~kg} / \mathrm{cm}^{2}\right)$ was measured by the mix code (50\%CKD- 200OPC)using ordinary Portland cementcontent of $200 \mathrm{~kg} / \mathrm{m} 3$ and $50 \%$ CKD. Physically, the reduction of compressive strength is attributed totheincrease in free limecontent in cement dust; the higher amount of $\mathrm{Ca}(\mathrm{OH})_{2}$ weakened the hardened matrix. Also, the formation of chloroandsulfo-aluminate phases leads to the softening and expansion ofthe hydration products. For all tested CKD/OPC ratio, the measured tested compressive strength of all specimens, largely exceed the limit imposed by the standard for load bearing bricks. It can be concluded from the actual study, that replacement of OPC content by $50 \%$ of CKD can be safely utilized in themanufacture of solid cement bricks used for load bearing walls.

\subsection{Flexural strength}

The effect of CKD/OPC ratio on the flexure strength of bricks is shown in Fig. 11 for all mixes. It confirms that flexure strength follows a similar trend as compressive strength. The flexure strength decreases with CKD content increase. For $30 \% \mathrm{CKD} / \mathrm{OPC}$ mix, bricks resulted in reduction in flexural strength by $18 \%$ and $16 \%$ for OPC nominal content of 200 and $250 \mathrm{~kg} / \mathrm{m}^{3}$ respectively.While. Using 50\% CKD, bricks decreased the flexural strength by $38 \%$ and $30 \%$ for 200 and $250 \mathrm{~kg} / \mathrm{m}^{3} \mathrm{OPC}$ content respectively. The flexure strength of Bricks tested in the current study follows the same trend resulted from experimental results carried out on Concrete mixtures by several researchers [12,13].

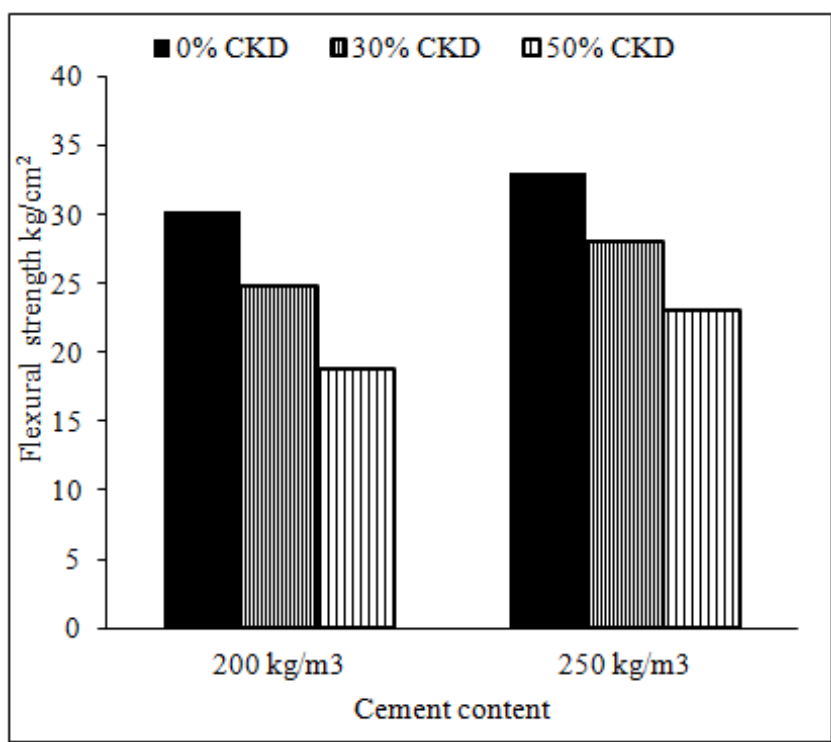

Fig. 11. Flexural strength of solid cement bricks at age 28 days.

\section{CONCLUSION}

In this study, the effect of using different amount of CKD to replace OPC in brick mixture has been investigated. Bricks were manufactured using two ratio of CKD/OPC (30\% and $50 \%)$ for two category of total Cement content $\left(200 \mathrm{~kg} / \mathrm{m}^{3}\right.$ and $250 \mathrm{~kg} / \mathrm{m}^{3}$ ). The specimen were tested to measure the variation in physical and mechanical properties. Test results showed that unit weight of solid cement bricks decreases with increasing quantity of CKD, whileabsorption increases when increasing CKD content. Compressive and flexural strength decreases when increasing CKD content and largely satisfy limit of load bearing bricks. At 50\% CKD/OPC ratio, the loss of Compressive strength and Flexural strength is $36 \%$ and $38 \%$ respectively.It is highlyrecommended to produce solid cement bricksusing up to $50 \%$ of $\mathrm{CKD} / \mathrm{OPC}$ ratio for manufacturing cheap, environmentally friendly bricks with the lowest carbon footprint and to contribute to the reduction of greenhouse gases and properly disposing of cement industrial waste.

\section{REFERENCES}

1. B.J. Zhan, C.. Poon, C.J. Shi, Materials characteristics affecting CO2 curing of concrete blocks containing recycled aggregates., Cem. Concr. Compos. 67. (2016). https://doi.org/10.1016/j.cemconcomp.

2. Taha R, Al-Rawas A, Al-Jabri K, Al-Harthy A, Hassan H, Al-Oraimi S, An overview of waste materials recycling in the Sultanate of Oman, in: Res Conserv Recycl, 2004: pp. 293-306.

3. Geiza E. Oliveira, Jose Nilson Holand, Use of mix of clay/solid waste from steel works for civil construction materials, Waste Manag. 22 (2004) 358-363.

4. C. RJ, Emery JJ, Kiln dust-fly ash systems for highways bases and sub-bases., Fed. Highw. Adm. (1983).

5. J.. Bhatty, Alternative Uses of Cement Kiln Dust, in: Portl. Cem. Assoc. Res. Dev., Bulletin RP327, Skokie, IL, 1995.

6. H.A. Udoeyo FF, Strengths of cement kiln dust concrete., J Mater Civ. Eng;14524-6. (2002).

7. K.B. Najim, Z.S. Mahmod, A.K.M. Atea, Experimental investigation on using Cement Kiln Dust (CKD) as a cement replacement material in producing modified cement mortar, Constr. Build. Mater. 55 (2014) 5-12. https://doi.org/10.1016/j.conbuildmat.2014.01.015.

8. BS-EN197-1:, Cement Part 1: Composition, Specifications and Conformity Criteria for Common Cements, Br. Stand. (2011) 50. 


\section{Physico-Mechanical Properties of Bricks Manufactured using Cement Kiln Dust}

9. ASTM C67, Standard Test Methods for Sampling and Testing Brick and Structural Clay Tile, Am. Soc. Test. Mater. i (2018) 1-12. https://doi.org/10.1520/C0067-11.

10. D.M. Sadek, M.M. El-attar, A.M. Salah, Recycling of high volumes of cement kiln dust in bricks industry, J. Clean. Prod. 143 (2017) 506-515. https://doi.org/10.1016/j.jclepro.2016.12.082.

11. ASTM C90, Standard specification for loadbearing concrete masonry units. Annual Book of ASTM Standards, (2014).

12. M.A. El-Mohsen, A.M. Anwar, I.A. Adam, Mechanical properties of Self-Consolidating Concrete incorporating Cement Kiln Dust, HBRC J. 11 (2014) 1-6. https://doi.org/10.1016/j.hbrcj.2014.02.007.

13. Al-Harthy AS, Taha R, Al-Maamary F, Effect of cement kiln dust (CKD) on mortar and concrete mixtures, Constr Build Mater. (2003) 60 